\title{
Genetic diversity and population structure in the Brazilian Cattleya labiata (Orchidaceae) using RAPD and ISSR markers
}

\author{
Lucas Rezende Pinheiro • Allívia Rouse Carregosa Rabbani • \\ Ana Veruska Cruz da Silva • Ana da Silva Lédo • \\ Katily Louise Garcia Pereira $\cdot$ Leandro Eugênio Cardamone Diniz
}

Received: 14 September 2011 / Accepted: 15 July 2012

(c) Springer-Verlag 2012

\begin{abstract}
Brazilian orchids are currently threatened with extinction due to habitat loss and, because of their high ornamental value, intense collecting pressure. Genetic diversity can play a key role in the survival of endangered orchid species. Here we provide the first data on genetic diversity and structure of wild populations in the genus Cattleya, in particular C. labiata, using random amplified polymorphic DNA (RAPD) and intersimple sequence repeat (ISSR) markers. We studied 130 individuals, 117 belonging to Cattleya labiata and 13 from 10 other species in the same genus. Data generated from 12 ISSR and 12 RAPD primers were used to determine genetic variability via a model-based Bayesian procedure (Structure) and molecular variance analysis. In addition, Shannon index, genetic diversity and Jaccard coefficients were also estimated. The marker data indicated that $C$. labiata has a high level of polymorphism, and five reconstructed populations were identified by Structure. The unweighted pair group method with arithmetic mean dendrogram did not group the samples by origin, which was also confirmed by Bayesian analysis, demonstrating the complex genetic structure of C. labiata. Other Cattleya species showed no
\end{abstract}

L. R. Pinheiro $(\varangle)$ · K. L. G. Pereira

Universidade Federal de Sergipe, Campus de São Cristóvão,

São Cristóvão, Sergipe 49100-000, Brazil

e-mail: lucaspinheiro@hotmail.com

A. R. C. Rabbani

Centro de Referência Para Recuperação de Áreas Degradadas,

Universidade Federal do Vale do São Francisco, Campus

Ciências Agrárias, Petrolina, Pernambuco 56300-000, Brazil

A. V. C. da Silva · A. da Silva Lédo - L. E. C. Diniz

Embrapa Tabuleiros Costeiros, Aracaju,

Sergipe 49025-040, Brazil relationship with any C. labiata sample. This genetic characterization of Cattleya from northeast Brazil contributes to knowledge of the genetic structure of the species and can be used to define strategies for conservation and breeding programmes.

Keywords Conservation - Endangered species - Genetic variability · Molecular markers · Orchid · Population structure

\section{Introduction}

The family Orchidaceae, one of the largest families of flowering plants, is characterized by its high species diversity and wide range of reproduction and distribution strategies, which have resulted in a variety of patterns of genetic differentiation among populations (Wallace 2003; Niknejad et al. 2009). The family is distributed worldwide, including on islands in Antarctica. There are almost no regions without orchids, as a result of their success in adapting to and colonizing almost every conceivable niche on land (Chase et al. 2003). Around 2,000 species, in 200 genera, are estimated to occur in Brazil. The species richness of Orchidaceae in Brazil is concentrated mainly in the Atlantic Forest ( $>50 \%$ ). The genus Cattleya Lindl. is highly important in floriculture and has been cultivated since the 19th century. It comprises 48 species distributed throughout mainland tropical America, usually as epiphytic plants of wet forests. Brazil is the centre of distribution, where more than half the species are found (Pabst and Dungs 1975; Cruz et al. 2003).

Orchidaceae contain the highest proportion of genera that include endangered species among all angiosperms, with about $6 \%$ of orchid species considered directly 
threatened (Hopper and Brown 2007). This is a result of over-collection due to their showy and highly appreciated flowers, combined with the difficulties of ex situ cultivation and constant threat to their natural habitats (Mello 2001; Li et al. 2002; Rodrigues 2010). In Brazil, Cattleya species are intensively collected because of their high ornamental value, which contributes to their risk of extinction (Cruz et al. 2003). This risk is even higher in the endemic Atlantic Forest because of its continuing exploitation (Pereira et al. 2005). The Brazilian Atlantic Forest is a biome of particular interest, as it is a global biodiversity hotspot with approximately 20,000 plant species, corresponding to a considerable proportion of the South American biodiversity (Myers et al. 2000). Of these species, C. labiata (Brazil 2008), which is native to the northeast coast of Brazil, is the best known. Considered the "Queen of Northeast Brazil" (Menezes 2002; Fontes 1989), it is sought after for its beauty, variety, fragrance and cultivability, being adaptable to different sites and substrate types.

Due to high levels of endemism and their sporadic and wide dispersal, removal of one tree or a few plants can seriously cripple the reproductive potential and gene flow of an entire orchid population. For species that are already endangered, especially those that are self-incompatible, reductions in gene flow can rapidly reduce fitness and adaptability (Pridgeon 1992). Knowledge about genetic diversity is extremely valuable to the preservation of endangered species, as loss of genetic variability may reduce survival chances in the wild (Swarts et al. 2009; Muñoz et al. 2010). Assessing genetic variation via morphological characters is difficult due to problems associated with variability caused by plant growth conditions (Wang et al. 2009). DNA-based molecular markers are not influenced by the environment, and in this context, molecular markers have been employed to study the genetic diversity of populations of Orchidaceae species (Qamaruz-Zaman et al. 1998; Fay and Chase 2009).

Only a few studies have used intersimple sequence repeats (ISSRs) to address orchid genetic diversity. ISSRs are highly polymorphic DNA markers that are present in both nuclear and organellar DNA, and consist of repeating units of one to six base pairs (Jarne and Lagoda 1996). Most species characterized by ISSR markers in this family are terrestrial (Smith et al. 2002; Wallace 2003; George et al. 2009; Wang et al. 2009). Random amplified polymorphic DNA (RAPD) markers are available for many orchid species (Lim et al. 1999; Sun and Wong 2001; Li et al. 2002; Li and Ge 2006; Niknejad et al. 2009), with the first study of Cattleya species having been conducted by Benner et al. (1995). Use of RAPDs does not require prior genomic knowledge, and is inexpensive and accessible, especially when molecular information is scarce (Costa et al. 2011; Silva et al. 2012). The technique is often criticized, however, because it usually shows low levels of repeatability and can therefore generate spurious bands (Sundberg et al. 2002; Ramos et al. 2008). The combination of RAPD and ISSR markers provides a quick, reliable and highly informative system, and has been used in many plant DNA fingerprinting and population genetic studies (Fernández et al. 2002; Shaw et al. 2009).

Genetic diversity and differentiation within and among C. labiata populations remain unknown, and molecular markers have not yet been used to characterize wild populations of this species in northeast Brazil. Accurate analysis of genetic variation within and among the remaining populations will provide basic information for establishing management practices to preserve this species. Our aims are thus to identify, classify and quantify the genetic variability of C. labiata in five wild and fragmented populations from northeast Brazil using RAPD and ISSR markers.

\section{Materials and methods}

\section{Plant material and DNA extraction}

DNA was isolated from young leaves as described by Doyle (1991). We used 130 genotypes, 117 belonging C. labiata and 13 from ten species (Table 1). One hundred and eleven genotypes of C. labiata were collected from five wild populations located in northeast Brazil (Fig. 1), and the other six samples (BVA, BVR, BVSM, UFLA 1, UFLA 2 and SAR) were obtained from orchid collections and commercial nurseries. Four Cattleya warneri T. Moore specimens were collected from a natural population in the city of São José da Vitória (Bahia State, $15^{\circ} 04^{\prime} 31.17^{\prime \prime}$ S, $39^{\circ} 20^{\prime} 21.54^{\prime \prime} \mathrm{W}$ ) (C. warn1 and C. warn2) and from a commercial nursery (CWC1 and CWC2) in Santa Bárbara (São Paulo State). Six specimens (Cattleya percivaliana Rchb. f., Cattleya maxima Lindley, Cattleya lueddemanniana Rchb. f., Cattleya schroeder Sander, Cattleya trianae Linden and Cattleya warscewiczii Rchb. f.) were acquired from orchid collections belonging to the Federal University of Lavras (UFLA), Minas Gerais State. Three samples (Cattleya lawrenceana Rchb. f., Cattleya wallissi Linden ex Rchb. f. and Cattleya gaskeliana Rchb. f.) were provided by a commercial grower (Bela Vista Orchids, Assis, São Paulo State).

Molecular markers

For RAPD, 11 primers (A01, A04, A09, A10, W02, W04, $\mathrm{W} 13, \mathrm{~W} 19, \mathrm{X} 01, \mathrm{X} 03$ and B01) from Operon (Operon Technologies, USA) and 1 primer (IDT09) from IDT Integrated DNA Technologies (Germany) were used to 
Table 1 One hundred and thirty genotypes of orchids (Cattleya sp.) from Brazil analysed by RAPD and ISSR markers

\begin{tabular}{|c|c|c|c|c|c|c|c|c|}
\hline GI & Species & Origin & GI & Species & Origin & GI & Species & Origin \\
\hline SE1 & C. labiata & PR & PB9 & C. labiata & Natuba & CE1.13 & C. labiata & Maranguape \\
\hline SE2 & C. labiata & PR & PB10 & C. labiata & Natuba & CE1.14 & C. labiata & Maranguape \\
\hline SE3 & C. labiata & PR & PB12 & C. labiata & Natuba & CE1.15 & C. labiata & Maranguape \\
\hline SE4 & C. labiata & PR & PB13 & C. labiata & Natuba & CE1.16 & C. labiata & Maranguape \\
\hline SE5 & C. labiata & PR & PB14 & C. labiata & Natuba & CE1.17 & C. labiata & Maranguape \\
\hline SE6 & C. labiata & PR & PB15 & C. labiata & Natuba & CE2.1 & C. labiata & Uruburetama \\
\hline SE7 & C. labiata & PR & PB16 & C. labiata & Natuba & CE2.2 & C. labiata & Uruburetama \\
\hline SE8 & C. labiata & PR & PB17 & C. labiata & Natuba & CE2.3 & C. labiata & Uruburetama \\
\hline SE10 & C. labiata & PR & PB18 & C. labiata & Natuba & CE2.4 & C. labiata & Uruburetama \\
\hline SE11 & C. labiata & PR & PB19 & C. labiata & Natuba & CE2.5 & C. labiata & Uruburetama \\
\hline SE12 & C. labiata & $\mathrm{PR}$ & PB20 & C. labiata & Natuba & CE2.6 & C. labiata & Uruburetama \\
\hline SE15 & C. labiata & PR & PE1 & C. labiata & BMD & CE2.7 & C. labiata & Uruburetama \\
\hline SE16 & C. labiata & PR & PE2 & C. labiata & BMD & CE2.8 & C. labiata & Uruburetama \\
\hline SE17 & C. labiata & PR & PE3 & C. labiata & BMD & CE2.9 & C. labiata & Uruburetama \\
\hline SE18 & C. labiata & PR & PE4 & C. labiata & BMD & CE2.10 & C. labiata & Uruburetama \\
\hline SE19 & C. labiata & PR & PE5 & C. labiata & BMD & CE2.11 & C. labiata & Uruburetama \\
\hline SE20 & C. labiata & PR & PE6 & C. labiata & BMD & CE2.12 & C. labiata & Uruburetama \\
\hline SE21 & C. labiata & PR & PE7 & C. labiata & BMD & CE2.13 & C. labiata & Uruburetama \\
\hline SE22 & C. labiata & PR & PE8 & C. labiata & BMD & CE2.14 & C. labiata & Uruburetama \\
\hline SE23 & C. labiata & PR & PE10 & C. labiata & BMD & CE2.15 & C. labiata & Uruburetama \\
\hline SE24 & C. labiata & PR & PE11 & C. labiata & BMD & CE2.16 & C. labiata & Uruburetama \\
\hline SE25 & C. labiata & PR & PE12 & C. labiata & BMD & CE2.17 & C. labiata & Uruburetama \\
\hline SE26 & C. labiata & PR & PE13 & C. labiata & BMD & CE2.18 & C. labiata & Uruburetama \\
\hline SE27 & C. labiata & PR & PE15 & C. labiata & BMD & BVA & C. labiata & Bela Vista \\
\hline SE28 & C. labiata & PR & PE16 & C. labiata & BMD & BVR & C. labiata & Bela Vista \\
\hline SE29 & C. labiata & PR & PE17 & C. labiata & BMD & BVSM & C. labiata & Bela Vista \\
\hline SE35 & C. labiata & PR & PE21 & C. labiata & BMD & SAR & C. labiata & Bela Vista \\
\hline SE36 & C. labiata & PR & PE22 & C. labiata & BMD & C. gaske & C. gaskelliana & Bela Vista \\
\hline SE37 & C. labiata & PR & PE23 & C. labiata & BMD & C. lawr & C. lawrenceana & Bela vista \\
\hline SE39 & C. labiata & PR & CE1.1 & C. labiata & Maranguape & C. eldora & C. wallissi & Bela Vista \\
\hline SE30 & C. labiata & PR & PE18 & C. labiata & BMD & UFLA 1 & C. labiata & UFLA \\
\hline SE31 & C. labiata & PR & PE19 & C. labiata & BMD & UFLA 2 & C. labiata & UFLA \\
\hline SE34 & C. labiata & PR & PE20 & C. labiata & BMD & C. warsc & C. warscewiczii & UFLA \\
\hline SE40 & C. labiata & PR & CE1.2 & C. labiata & Maranguape & C. luedd & C. lueddemanniana & UFLA \\
\hline SE41 & C. labiata & PR & CE1.3 & C. labiata & Maranguape & C. $\operatorname{maxi}$ & C. maxima & UFLA \\
\hline SE42 & C. labiata & PR & CE1.4 & C. labiata & Maranguape & C. perciv & C. percivaliana & UFLA \\
\hline PB1 & C. labiata & Natuba & CE1.5 & C. labiata & Maranguape & C. schro & C. schroeder & UFLA \\
\hline PB2 & C. labiata & Natuba & CE1.6 & C. labiata & Maranguape & C. trian & C. trianae & UFLA \\
\hline PB3 & C. labiata & Natuba & CE1.7 & C. labiata & Maranguape & CWC1 & C. warneri & Santa Bárbara \\
\hline PB4 & C. labiata & Natuba & CE1.8 & C. labiata & Maranguape & $\mathrm{CWC} 2$ & C. warneri & Santa Bárbara \\
\hline PB5 & C. labiata & Natuba & CE1.9 & C. labiata & Maranguape & C. warn 1 & C. warneri & SJV \\
\hline PB6 & C. labiata & Natuba & CE1.10 & C. labiata & Maranguape & C. warn 2 & C. warneri & SJV \\
\hline PB7 & C. labiata & Natuba & CE1.11 & C. labiata & Maranguape & & & \\
\hline PB8 & C. labiata & Natuba & CE1.12 & C. labiata & Maranguape & & & \\
\hline
\end{tabular}

GI genotype identification, PR Poço Redondo, BMD Brejo da Madre de Deus, UFLA Federal University of Lavras, SJV São José da Vitória 


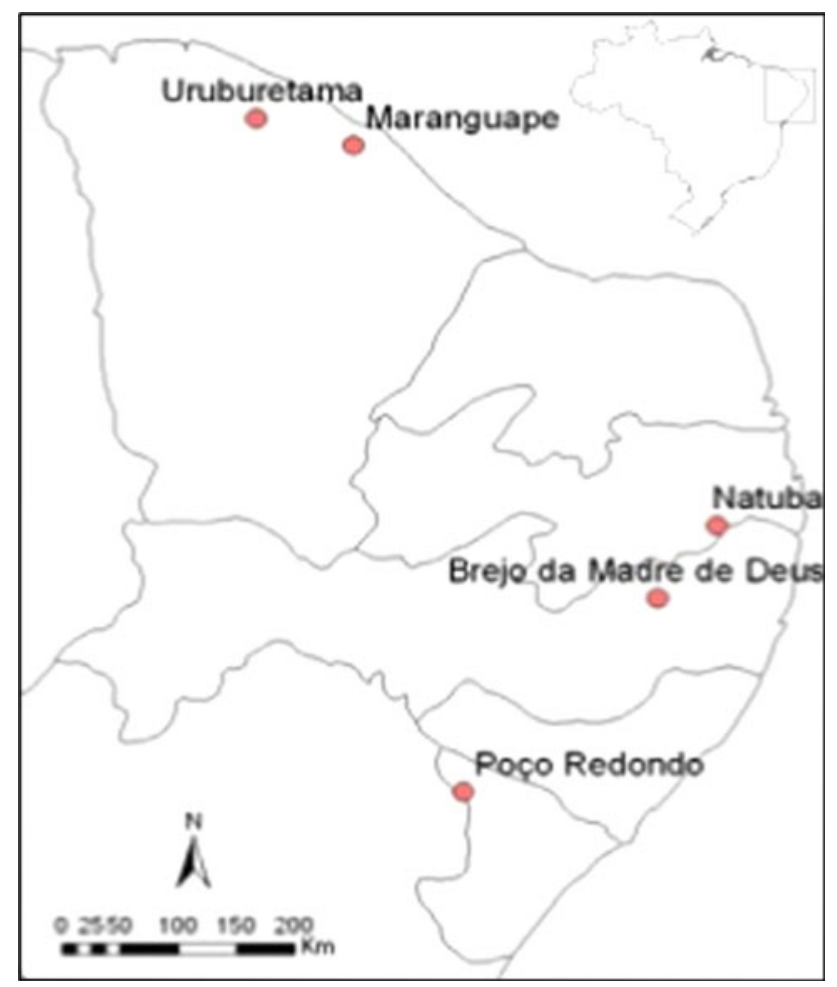

Fig. 1 Geographic location of 111 native orchids (Cattleya labiata) collected from five cities in Brazil

screen for polymorphisms (Table 2). Polymerase chain reaction (PCR) amplifications were performed using a PTC-100 thermocycler (MJ Research), with reactions consisting of $5 \mathrm{~min}$ initial denaturation at $96{ }^{\circ} \mathrm{C}$, followed by 35 cycles of denaturation at $96{ }^{\circ} \mathrm{C}$ for $45 \mathrm{~s}$, primer annealing at $36{ }^{\circ} \mathrm{C}$ for $45 \mathrm{~s}$ and extension at $72{ }^{\circ} \mathrm{C}$ for $45 \mathrm{~s}$, and one final extension step of $72{ }^{\circ} \mathrm{C}$ for $10 \mathrm{~min}$.

For ISSR, 12 primers $(807,810,814,826,834,835,841$, $843,844 \mathrm{~B}, 845,855$ and HB10) obtained from IDT were used to screen for polymorphisms (Table 2). PCR amplification was performed as follows: $95^{\circ} \mathrm{C}$ for $5 \mathrm{~min}$ for initial denaturation, followed by 45 cycles of denaturation at $94{ }^{\circ} \mathrm{C}$ for $1 \mathrm{~min}, 51.5^{\circ} \mathrm{C}(843,845,855), 52{ }^{\circ} \mathrm{C}(807$, $810,814,835,841,844 \mathrm{~B}, \mathrm{HB} 10)$ or $52.5^{\circ} \mathrm{C}(826,834)$ for $45 \mathrm{~s}$ for primer annealing and $72{ }^{\circ} \mathrm{C}$ for $2 \mathrm{~min}$ for extension, and one final extension of $72{ }^{\circ} \mathrm{C}$ for $10 \mathrm{~min}$. Fragments were visualized on $2 \%$ agarose gel $[1 \times$ TBE$89 \mathrm{mM}$ Tris, $89 \mathrm{mM}$ boric acid, $2.5 \mathrm{mM}$ ethylenediamine tetraacetic acid (EDTA), pH 8.3] in a horizontal electrophoresis system (Sunrise, Gibco BRL) run at constant voltage of $100 \mathrm{~V}$ for $90 \mathrm{~min}$. The gel was stained with ethidium bromide solution $(5 \mathrm{mg} / \mathrm{mL})$ for $15 \mathrm{~min}$. ISSR and RAPD amplification products were visualized under ultraviolet light using a Gel Doc L-Pix imaging system (Loccus Biotecnologia, Brazil).
Table 2 Number of polymorphic fragments (TF) generated by each primer from 130 genotypes of Cattleya sp. from northeastern Brazil

\begin{tabular}{lrrrr}
\hline RAPD & & & ISSR \\
\cline { 5 - 5 } Primer & TF & & Primer & TF \\
\hline A01 & 10 & & 814 & 11 \\
A04 & 9 & & $844 B$ & 17 \\
A09 & 9 & & HB10 & 12 \\
A10 & 11 & 807 & 10 \\
B01 & 8 & & 810 & 16 \\
IDT09 & 8 & & 826 & 12 \\
W02 & 9 & 834 & 11 \\
W04 & 10 & 835 & 12 \\
W13 & 11 & 841 & 16 \\
W19 & 11 & 843 & 15 \\
X01 & 14 & 845 & 16 \\
X03 & 11 & 855 & Total \\
Total & 121 & &
\end{tabular}

Data analysis

Only data from intensely stained, unambiguous, clear fragments were used for statistical analysis. RAPD and ISSR markers were scored as present (1) or absent (0). RAPD results were congruent with those from ISSR markers, supporting the reliability of the technique for our study. All data obtained were combined and used to analyse genetic parameters as recommended by Awasthi et al. (2004) and Bhattacharya et al. (2005).

The minimum number of fragments required to conduct the genetic diversity study was based on Oliveira et al. (2010), and these were analysed by the bootstrap method (Manly 1997) with 10,000 replicates using the Genes software package (http://www.ufv.br/dbg/genes/Genes_ EUA.htm). The number of polymorphic fragments was considered optimal when the assumed stress value was $<0.05$ (Kruskal 1964).

A data matrix of RAPD and ISSR scores was generated, and similarity coefficients were calculated using Jaccard's arithmetic complement index (Jaccard 1908). A dendrogram was constructed using the unweighted pair group method with arithmetic mean (UPGMA) cluster algorithm. To determine dendrogram robustness, the data were bootstrapped with 7,000 replicates using FreeTree software (http://web.natur.cuni.cz/flegr/programs/freetree.htm), and TreeView (http://web.natur.cuni.cz/flegr/programs/freetree/ TreeView.exe) was used for cluster visualization. Principal coordinate analysis (PCoA) was performed using the software package XLSTAT (http://www.xlstat.com/) based on the calculated Jaccard's similarity coefficients. 
Inferences regarding genetic structure within Cattleya genotypes were made using Structure version 2.2 (Pritchard et al. 2000; Falush et al. 2007). For our analysis, each genotype class was treated as if it contained haploid alleles, following the software protocol and Oliveira et al. (2010). We estimated $K$, the number of reconstructed panmictic populations (RPPs) of individuals, using values ranging from 1 to 10 and assuming that the sampled genotypes were from anonymous plants of unknown origin (usepopinfo and popflag set to 0 ). We set up runs with a 20,000-iteration burn-in period and a Monte Carlo Markov chain (MCMC) of 20,000 iterations, with five repetitions. The program Structure estimates the most likely number of clusters $(K)$ by calculating the log probability of data for each value of $K$ (Santos et al. 2011). We assessed the best $K$ value supported by the data according to Evanno et al. (2005).

The Shannon index (I) (Brown and Weir 1983) and genetic diversity $(H)$ were calculated as described by Lynch and Milligan (1994) and Maguire et al. (2002), using Genalex v.6.3 (www.anu.edu.au/BoZo/GenAlEx/). The same software package was employed to conduct analysis of molecular variance (AMOVA) (Excoffier et al. 1992; Michalakis and Excoffier 1996).

\section{Results}

\section{Molecular markers}

A total of 272 DNA fragments (151 ISSR and 121 RAPD), all polymorphic, were generated using the 24 primers (Table 2). Of the RAPD primers, X01 produced the highest number of fragments (14); the most productive ISSR primer was 844B (17). Using the genetic parameters recommended by Awasthi et al. (2004) and Bhattacharya et al. (2005), we found a high correlation between marker matrices, allowing RAPD and ISSR data to be combined to measure the genetic parameters. Results of bootstrap analyses are shown in Fig. 2. For the 272 polymorphic fragments, the correlation $(r)$ was 0.98 and the stress value (sv) was 0.05 (Kruskal 1964). The 272 polymorphic fragments generated by the RAPD and ISSR reactions from the orchid genotypes showed excellent precision, with a high correlation between the RAPD and ISSR data $(r=0.56$; $P \leq 0.0001)$ according to the Mantel test (Mantel 1967).

Genetic similarity

Jaccard coefficients (JCs) ranged from 0.14 (C. trianae and SE21) to 0.82 (CE2.10 and CE2.7), with average similarity of 0.45 . Within each population, JCs ranged from 0.29 (SE21 and SE28) to 0.74 (SE22 and SE23) for Poço

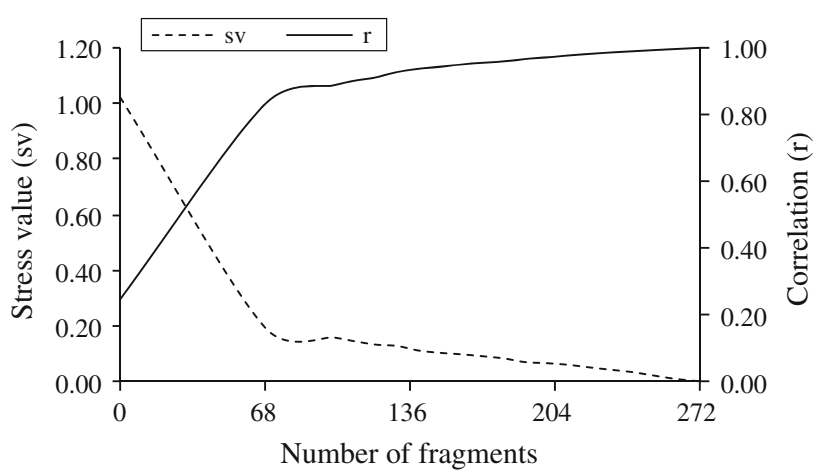

Fig. 2 Correlation $(r)$ and stress values (sv) for the number of polymorphic fragments using RAPD and ISSR markers for 130 genotypes of orchids (Cattleya sp.) from Brazil

Redondo (Sergipe), 0.36 (PB8 and Pb20) to 0.70 (PB15 and PB16) for Natuba (Paraíba), 0.25 (PE6 and PE17) to 0.77 (PE15 and PE16) for Brejo da Madre de Deus (Pernambuco), 0.30 (CE1.5 and CE1.17) to 0.75 (CE1.12 and CE1.13) for Maranguape (Ceará), 0.33 (CE2.2 and CE2.9) to 0.82 (CE2.10 and CE2.7) for Uruburetama (Ceará), and finally, for the reference genotypes, 0.13 (Cattleya maxima and PE6) to 0.48 (CWC2 and BVA). The mean similarity within each population was $0.56,0.51$, 0.48, 0.57, 0.60 and 0.36 for Poço Redondo, Natuba, Brejo da Madre de Deus, Maranguape, Uruburetama and reference genotypes, respectively.

Genotypes were clustered by UPGMA using the JCs estimated from the binary data of 130 genotypes (Fig. 3a). The distribution of genotypes in the clusters showed the separation of the different species, as well as the high divergence of some genotypes belonging to natural populations of C. labiata (PE17-0.43 JC, PE19-0.43 JC, SE28-0.37 JC, PE6-0.37 JC, SE21-0.33 JC, PB80.37 JC, CE2.2-0.35 JC, PE25-0.33 JC, CE1.5-0.35 JC). One large group contained most of the genotypes from the Sergipe population and some genotypes from the other populations. Another cluster grouped more than half of the genotypes from both Ceará State populations. Genotypes from the populations of Natuba (Paraíba) and Brejo da Madre de Deus (Pernambuco) were randomly distributed among the other genotypes, showing relationships with all other populations. The $C$. labiata species used as a reference (UFLA1, UFLA2, BVR, BVA, BVSM and SAR) were more similar to CE2.18 (0.63 JC), BVA (0.64 JC), CE2.13 (0.59 JC), UFLA2 (0.64 JC), BVA (0.68 JC) and BVA (0.65 JC), respectively, showing more similarity between them and some genotypes from the Uruburetama (Ceará) population. C. lawrenceana, C. wallissi and C. percivaliana were more similar to Cattleya shcroeder (0.39 JC), C. percivaliana (0.49 JC) and C. wallissi (0.49 JC), respectively. 
Fig. 3 (a) UPGMA

dendrogram of genetic

similarity generated from

Jaccard coefficients (b) and

reconstructed populations (RPP

1-5) defined using Structure

(Pritchard et al. 2000) for 130

orchid (Cattleya sp.) genotypes

from Brazil using RAPD and

ISSR markers (a)

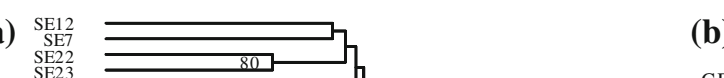

(b)

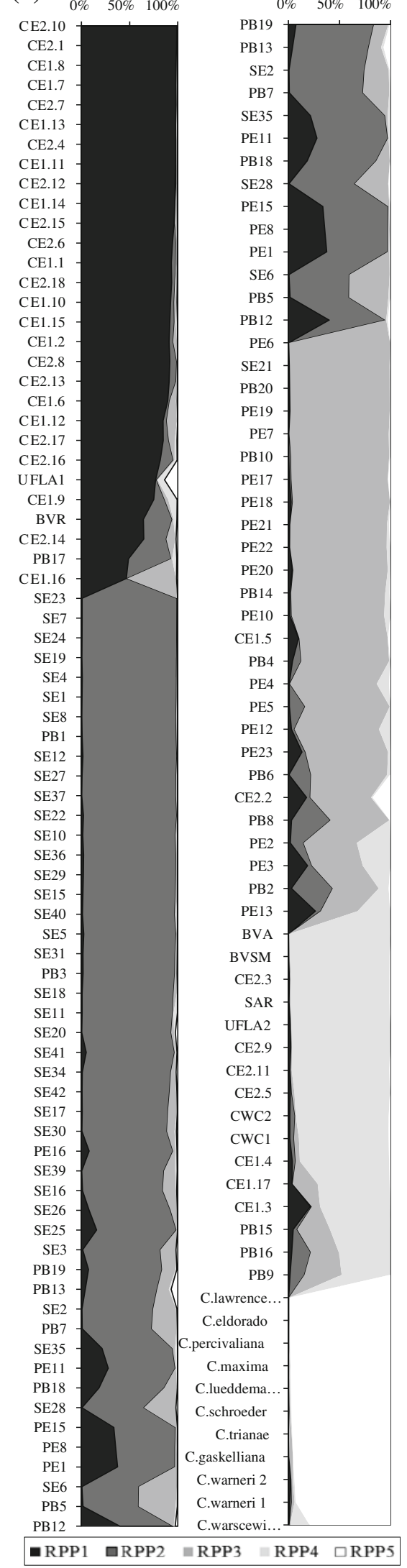


Genetic structure and diversity

Bayesian (Structure) analysis was conducted to determine the genetic structure among the orchid genotypes. This clustering approach assigns individuals to RPPs based on genotype. The Structure program estimates the most likely number of clusters $(K)$ by calculating the log probability of data for each value of $K$, and using $\Delta K$ statistics described by Evanno et al. (2005) as recommended by Barnaud et al. (2007) and Santos et al. (2011). The best $K$ for representing the RPP genotypes was $K=5$ (RPP1-RPP5) (Fig. 3b).

The first RPP (RPP1) included 29 genotypes, of which 23 from Ceará State had probability of membership $(\mathrm{q} I)>80 \%$. Six genotypes with $\mathrm{q} I<80 \%$, including two reference genotypes (UFLA1 and BVR), three genotypes from Maranguape (CE1.9, CE2.14 and CE1.16) and one from Natuba (PB17) were also assigned to this RPP. The second RPP (RPP2) included 48 genotypes, 34 of which were from Poço Redondo, Brejo da Madre de Deus and Natuba, and had $\mathrm{q} I>80 \%$. Of the 18 genotypes with $\mathrm{q} I<80 \%$, four were from Poço Redondo (SE2, SE6, SE28 and SE35), four were from Brejo da Madre de Deus (PE1, PE8, PE11 and PE15) and six were from Natuba (PB5, PB7, PB12, PB13, PB18 and PB19). The third RPP (RPP3) clustered 26 genotypes, 19 with $\mathrm{q} I>80 \%$. The seven genotypes with $\mathrm{q} I>80 \%$ included one from Maranguape (CE2.2), three from Brejo da Madre de Deus (PE2, PE3 and PE13) and three from Natuba (PB2, PB6 and PB8). The fourth RPP (RPP4) clustered 15 genotypes, 11 with $\mathrm{q} I>80 \%$, including six reference genotypes (BVA, BVSM, SAR, UFLA2, CWC2 and CWC1). The five genotypes with $\mathrm{q} I<80 \%$ included two from Maranguape (CE1.3 and CE1.17) and three from Natuba (PB15, PB16 and PB9). The fifth RPP (RPP5) clustered 11 genotypes of the reference species, all with $\mathrm{q} I>80 \%$ (Fig. 3b).

The multivariate ordering (PCoA; Fig. 4), to the first two principal coordinates, explained $14.21 \%$ of total variability.

All the populations demonstrated similar mean genetic diversity. The Shannon index was 0.29 for populations according to origin, with an incrementally larger value when using the reconstructed populations (0.30). A high value was obtained for the 10 species used as references (0.36). The genetic diversity was 0.19 for populations according to origin and reconstructed population. For the original populations of $C$. labiata, the maximum genetic diversity ( $I$ and $H$ ) was associated with Natuba (Paraíba), and for RPPs, RPP1 and RPP4. The percentage of polymorphic loci among populations was $62.03 \%$ according to origin and $67.43 \%$ according to RPP (Table 3 ).

AMOVA performed between the 130 different genotypes according to their original location showed low genetic differentiation $(15 \%, P<0.001)$, and when analysed according

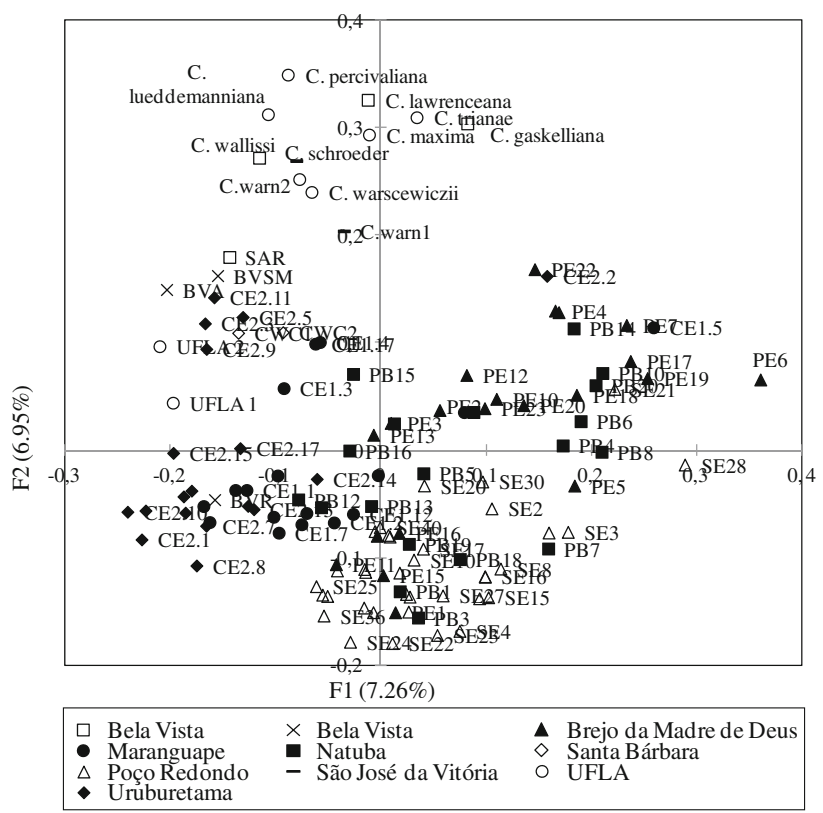

Fig. 4 Principal coordinate analysis of 130 orchid (Cattleya sp.) genotypes collected from 10 localities in Brazil based on RAPD and ISSR marker data

to RPP, genetic differentiation only accounted for $20 \%$ $(P<0.001)$ of the variation. When we analysed $C$. labiata alone by origin, the genetic variation among populations was only $13 \%(P<0.001)$ and by RPPs only $18 \%(P<0.001)$ (Table 4).

\section{Discussion}

The high levels of polymorphism found in the genus Cattleya in this study were also detected by Benner et al. (1995) using RAPD markers. There was a direct relationship between the number of fragments analysed and the magnitude of correlation values obtained via the bootstrap method. According to Kruskal (1964), the number of fragments among the orchid genotypes showed excellent precision to genetic analyses [272 $(0.00 \mathrm{sv})]$.

This study was the first to use ISSRs in combination with RAPD markers to assess genetic diversity in C. labiata. None of the individual plants were genetically identical according to the Jaccard similarity index, indicating that the level of resolution in this study was sufficient to distinguish all genotypes. In the UPGMA dendrogram, which was based on the Jaccard similarity index, genotypes were not grouped by origin. These results were confirmed by bootstrap and Bayesian analyses, demonstrating the complex genetic structure of the species. The variation explained by CP1 and CP2 was low (14.21\%), but the PCoA results confirmed the difference between the reference species and samples of C. labiata. 
Table 3 Shannon index $(I)$, genetic diversity $(H)$ and percentage of polymorphic loci $(P \%)$ in 130 genotypes of orchids $($ Cattleya sp.) from northeastern Brazil by origin and by reconstructed population (RPP) defined by Structure (RPP 1-5) software using RAPD and ISSR markers

\begin{tabular}{|c|c|c|c|}
\hline Origin & $I( \pm \mathrm{SD})$ & $H( \pm \mathrm{SD})$ & $P \%$ \\
\hline Poço Redondo (Sergipe) & $0.27( \pm 0.02)$ & $0.18( \pm 0.01)$ & 59.56 \\
\hline Natuba (Paraíba) & $0.30( \pm 0.02)$ & $0.20( \pm 0.01)$ & 64.34 \\
\hline Brejo da Madre Grande (Pernambuco) & $0.28( \pm 0.02)$ & $0.18( \pm 0.01)$ & 63.60 \\
\hline Maranguape (Ceará) & $0.29( \pm 0.02)$ & $0.19( \pm 0.01)$ & 58.82 \\
\hline Uruburetama (Ceará) & $0.27( \pm 0.02)$ & $0.18( \pm 0.01)$ & 54.78 \\
\hline Reference genotypes from $C$. labiata & $0.25( \pm 0.02)$ & $0.17( \pm 0.01)$ & 48.53 \\
\hline Reference genotypes from other Cattleya species & $0.36( \pm 0.01)$ & $0.22( \pm 0.01)$ & 84.56 \\
\hline Total & $0.29( \pm 0.01)$ & $0.19( \pm 0.01)$ & 62.03 \\
\hline \multicolumn{4}{|l|}{ Reconstructed population } \\
\hline RPP1 & $0.29( \pm 0.02)$ & $0.19( \pm 0.01)$ & 60.66 \\
\hline RPP2 & $0.28( \pm 0.02)$ & $0.19( \pm 0.01)$ & 64.71 \\
\hline RPP3 & $0.27( \pm 0.01)$ & $0.17( \pm 0.01)$ & 67.28 \\
\hline RPP4 & $0.29( \pm 0.02)$ & $0.19( \pm 0.01)$ & 59.93 \\
\hline RPP5 & $0.36( \pm 0.01)$ & $0.22( \pm 0.01)$ & 84.56 \\
\hline Total & $0.30( \pm 0.01)$ & $0.19( \pm 0.01)$ & 67.43 \\
\hline
\end{tabular}

SD standard deviation

Table 4 Analysis of molecular variance (AMOVA) of 130 genotypes of orchids (Cattleya sp.) using RAPD and ISSR markers classified by origin and by reconstructed population (RRP) defined by Structure $(K=5)$

\begin{tabular}{lrrr}
\hline & $d f$ & Est. variance & Variation $(\%)$ \\
\hline Origin & 5 & 5.18 & $15^{* * *}$ \\
Among & 124 & 29.18 & 85 \\
Within & & & 4.24 \\
C. labiata by origin & 4 & 27.21 & $13 * * *$ \\
Among & 106 & & 87 \\
Within & & 7.09 & $20 * * *$ \\
RPPs & 4 & 28.06 & 80 \\
Among & 125 & & $18^{* * *}$ \\
Within & & 5.92 & 82 \\
4 RPPs (without RPP5) & 3 & 26.72 & \\
Among & 115 & & \\
Within & & & \\
\hline
\end{tabular}

$d f$ degrees of freedom

*** $P<0.001$

The genotype pairs CWC1 and CWC2, donated by Santa Barbara Orchids, and cwarn1 and cwarn2, collected from a wild Sao José da Vitoria population belonging to $C$. warneri, did not group together in the UPGMA analysis. Cultivated plants were morphologically distinct from wild plants, mainly in characteristics such as flower number and shape, consistent with the domestication syndrome (Wang et al. 1999). Genotypes of C. labiata from Natuba and Brejo da Madre de Deus were present in clusters containing genotypes from other locations, such as Poço Redondo and Ceará, which is correlated with the geographical distribution pattern of the populations. Menezes (2002) studied species in different habitats in northeastern Brazil and found that it was possible to distinguish the flowers of C. labiata based on their geographical occurrence: those from Ceará State populations, particularly those from Uruburetama, had darker coloration, were smaller, and better shape when compared with plants from populations in the States of Paraíba and Pernambuco.

Distribution of genetic variation can be influenced by various life-history traits, with breeding system having a particularly significant effect (Nybom and Bartish 2000). The majority of orchids are allogamous, being pollinated by animals (e.g. hummingbirds, bees and butterflies). Allogamous species, by definition, are much more variable than those that are autogamous (Yanaka et al. 2005). 
Theoretical work has established that the time required for loss of genetic variability is inversely correlated with effective population size (Hartl and Clark 1989; Meffe and Carroll 1997; Hedrick 2000). It is generally agreed that $C$. labiata is experiencing a drastic population decline as a result of the high degree of fragmentation in the Atlantic Forest in northern Brazil. C. labiata is distributed in the Atlantic Forest from Sergipe to Ceará, and this ecological amplitude may be associated with a high genetic variability among the geographic populations that was not found by our analysis. According to Swarts et al. (2009), $5 \%$ of the total genetic variation found between populations of another orchid species (Caladenia huegelii Rchb. f.) suggested anemochorous dispersion of seeds over long distances, which would facilitate gene flow between populations. The genetic similarity between individuals of $C$. labiata to those from different regions also suggests anemochorous dispersion of its seeds over long distances. This may also be related to their perennial long-lived habit, which may have ensured the maintenance of old genotypes from genetic material that was exchanged when C. labiata was distributed uniformly along the northeastern Brazilian coast. Another reason for this pattern could be the special microstructure within populations that is possible due to biotic processes (such as clonal growth or short-distance scattering), as observed in epiphytic plants such as Laelia rubescens Lindl (Trapnell et al. 2004).

The genetic diversity indices in our study indicate higher levels of within-population differentiation compared with studies of other Orchidaceae species using dominant markers. Low genetic diversity values were found in 8 populations of Piperia yadonii R. Morgan and Ackerman (0.06-0.05; George et al. 2009), in 4 populations of Paphiopedilum micranthum Tang and F. T. Wang (0.15; Li et al. 2002) and in 11 populations of Changnienia amoena S. S. Chien (0.12; Li and Ge 2006). Diversity indices are higher in orchids with epiphytic habit, such as $C$. labiata, than in terrestrial orchids, as they have different survival strategies; examples include the occurrence of individuals with allogamous and autogamous breeding systems and perennial plants with long lifespans (Ávila-Díaz and Oyama 2007). On the other hand, low genetic diversity indices may be due to the dominant marker-based methods used to estimate allele frequency, as well as phenomena such as habitat fragmentation and high collecting pressure that promote genetic drift and limit gene flow between populations ( $\mathrm{Li}$ et al. 2002; Li and Ge 2006; Parab and Krishnan 2008).

The results of population genetics analysis by origin showed that genetic variability among populations of C. labiata was low. This variation within populations was higher in AMOVA, and increased further when we considered RPPs. Similar results were found in the endemic C. elongata from nine regions of northeastern Brazil, in which low divergence was detected between populations (18\%) (Cruz et al. 2011).
Low levels of genetic differentiation within populations have been reported for wild orchids (Nybom and Bartish 2000; Sun and Wong 2001), which according to Li et al. (2002; Li and Ge 2006) may be the result of habitat fragmentation. C. labiata has declined dramatically in recent years as habitat destruction has reduced the number of populations (Swarts et al. 2009). Habitat protection is the top priority for $C$. labiata given the fact that its habitats have been both destroyed and fragmented due to exploitation and agricultural practice in recent decades. The populations examined in our study are not located in protected areas, but should be made a priority in the conservation of this orchid species. This study will assist in developing viable strategies for the maintenance and conservation of genetic diversity within these orchid populations.

In species featuring high levels of genetic differentiation between populations, loss of a population can cause irreversible loss of genetic variation that is not shared with other populations (Soul'e 1986; Hossaert McKey et al. 1996; Chung et al. 2003). The 130 genotypes evaluated in this study, however, were found to form a monophyletic group based on JCs. This genetic characterization may be useful in regional conservation programmes, e.g. the creation of a germplasm bank. Genetic variability was relatively high, and similar values were found in wild populations of C. elongata Barb. from Chapada Diamantina (northeastern Brazil) using ISSR markers (Cruz et al. 2011). Because genetic variation is fundamentally involved in the survival and evolution of any species, our results have direct implications for the conservation and management of $C$. labiata and its relationship with other Cattleya species.

When grouped into discrete populations and regions, UPGMA and AMOVA showed no significant genetic differentiation among the natural populations. It would be worthwhile to develop specific microsatellite markers that may be used to reveal fine-scale population structure and detect alleles that dominant markers such as RAPD and ISSR cannot identify (Selkoe and Toonen 2006). Future work should focus on sampling more populations across the distributional range of $C$. labiata to test whether such populations are genetically distinct. Much work remains to be done to understand the factors governing orchid species distribution and abundance. Two courses of action are required to conserve $C$. labiata: land preservation and prevention of collection from the wild. This will require management and policing to prevent illegal removal of orchids.

\section{Conclusions}

This study, the first report on C. labiata in northeastern Brazil, is a contribution to the characterization of native 
genotypes. The genetic variation and genetic relationships among wild C. labiata were efficiently determined using RAPD and ISSR markers. The identification of $C$. labiata from northeastern Brazil contributes to our knowledge of genetic relationships and the strategies required to protect natural populations and preserve genetic variability. For $C$. labiata, the most appropriate strategy would be habitat protection.

Acknowledgments This study was funded by Embrapa Coastal Tablelands. Coordenação de Aperfeiçoamento de Pessoal de Nível Superior (CAPES) supported L.R.P. during his studies.

\section{References}

Ávila-Díaz I, Oyama K (2007) Conservation genetics of an endemic and endangered epiphytic Laelia speciosa(Orchidaceae). Am J Bot 94:184-193

Awasthi AK, Nagaraja GM, Naik GV, Kanginakudru S, Thangavelu K, Nagaraju J (2004) Genetic diversity and relationships in mulberry (genus Morus) as revealed by RAPD and ISSR markers. Genetics 5:1-9. doi:10.1186/1471-2156-5-1

Barnaud A, Deu M, Garine E, McKey D, Joly HI (2007) Local genetic diversity of sorghum in a village in northern Cameroon: structure and dynamics of landraces. Theor Appl Genet 114:237-248. doi: 10.1007/s00122-006-0426-8

Benner MS, Braunstein MD, Weisberg MU (1995) Detection of DNA polymorphisms within the genus Cattleya (Orchidaceae). Plant Mol Biol Rep 13:147-155. doi:10.1007/BF02668786

Bhattacharya E, Dandin SB, Ranade SA (2005) Single primer amplification reaction methods reveal exotic and indigenous mulberry varieties are similarly diverse. Biosci J 30:669-677. doi:10.1007/BF02703567

Brazil (2008) Instrução Normativa n.6, de 23 de setembro de 2008. Lista oficial das espécies da flora brasileira ameaçadas de extinção, vol 145(185). Diário Oficial da República Federativa do Brasil, Brasília, DF, 24 set. 2008. Seção 1, pp 75-83. Ministério do Meio Ambiente. http://www.ibama.gov.br/recursos-florestais/wp-content/ files/IN-MMA_06-2008.pdf. Accessed 15 Jan 2011

Brown AHD, Weir BS (1983) Measuring genetic variability in plant populations. In: Orton TJ, Tanksley SD (eds) Isozymes in plant genetics and breeding. Elsevier Science, Amsterdam, pp 219-239

Chase MW, Cameron KM, Barrett R, Freudenstein JV (2003) DNA data and Orchidaceae systematics: a new phylogenic classification. In: Dixon KW, Kell SP, Barrett RL, Cribb PJ (eds) Orchid conservation. Natural History, Kota Kinabalum, pp 69-90

Chung MY, Epperson BK, Chung MG (2003) Genetic structure of age classes in Camellia japonica (Theaceae). Evolution 57:62-73

Costa TS, Silva AVC, Lédo AS, Santos ARF, Silva JF Jr (2011) Diversidade genética de acessos do banco de germoplasma de mangaba em Sergipe. Pesq Agropec Bras 46:499-508. doi: 10.1590/S0100-204X2011000500007

Cruz DT, Borba EL, Van den Berg C (2003) O gênero Cattleya (Orchidaceae) no estado da Bahia, Brasil. Sitientibus Ser Ci Bio 3:26-34

Cruz DT, Selbach-Schnadelbach A, Lambert SM, Ribeiro PL, Borba EL (2011) Genetic and morphological variability in Cattleya elongata Barb. Rodr. (Orchidaceae), endemic to the campo rupestre vegetation in northeastern Brazil. Plant Syst Evol 294:87-98. doi:10.1007/s00606-011-0444-0

Doyle J (1991) DNA protocols for plants-CTAB total DNA isolation. In: Hewitt GM, Johnston A (eds) Molecular techniques in taxonomy. Springer, Berlin, pp 283-293
Evanno G, Regnaut S, Goudet J (2005) Detecting the number of clusters of individuals using the software Structure: a simulation study. Mol Ecol 14:2611-2620. doi:10.1111/j.1365-294X.2005. 02553.x

Excoffier L, Smouse PE, Quattro JM (1992) Analysis of molecular variance inferred from metric distances among DNA haplotypes: application to human mitochondrial DNA restriction data. Genetics 131:479-491

Falush D, Mand S, Pritchard JK (2007) Inference of population structure using multilocus genotype data: dominant markers and null alleles. Mol Ecol Notes 7:574-578. doi:10.1111/j.14718286.2007.01758.x

Fay MF, Chase MW (2009) Orchid biology: from Lennaeus via Darwin to the 21st century. Ann Bot 104:359-364. doi:10.1093/ aob/mcp 190

Fernández ME, Figueiras AM, Benito C (2002) The use of ISSR and RAPD markers for detecting DNA polymorphism, genotype identification and genetic diversity among barley cultivars with known origin. Theor Appl Genet 104:845-851. doi:10.1007/ s00122-001-0848-2

Fontes JPS (1989) A rainha do nordeste brasileiro: Cattleya labiata Lindley. Edição Europa, Rio de Janeiro

George S, Sharma J, Yadon VL (2009) Genetic diversity of the endangered and narrow endemic Piperia yadonni (Orchidaceae) assessed with ISSR polymorphisms. Am J Bot 96:2020-2022. doi:10.3732/ajb.0800368

Hartl DL, Clark AG (1989) Principles of population genetics. Sinauer, MA

Hedrick PW (2000) Genetics of populations. Jones and Barlett, London

Hopper SD, Brown AP (2007) A revision of Australia's hammer orchids (Drakaea: Orchidaceae), with some field data on species-specific sexually deceived wasp pollinators. Austral Syst Bot 20:252-285. doi:10.1071/SB06033

Hossaert Mckey M, Valero M, Magda D, Jarry M, Cuguen J, Vernet P (1996) The evolving genetic history of a population of Lathyrus sylvestris: evidence from temporal and spatial genetic structure. Evolution 50:1808-1821

Jaccard P (1908) Nouvelles recherches sur la distribution florale. Soc Vaud Sci Nat 44:223-270

Jarne P, Lagoda PJL (1996) Microsatellites from molecules to populations and back. Trends Ecol Evol 11:424-429. doi: 10.1016/0169-5347(96)10049-5

Kruskal JB (1964) Multidimensional scaling by optimizing goodness of fit to a no metric hypothesis. Psychometrika 29:1-27

Li A, Ge S (2006) Genetic variation and conservation of Changnienia amoena, an endangered orchid endemic to China. Plant Syst Evol 258:251-260

Li A, Luo Y, Ge S (2002) Premilary study on conservation genetics of an endangered orchid (Paphiopedilum micranthum) from southwestern China. Biochem Genet 40:195-201

Lim SH, Teng PCP, Lee YH, Goh JG (1999) RAPD analysis of some species in the genus Vanda (Orchidaceae). Ann Bot 83:193-196

Lynch M, Milligan BG (1994) Analysis of population genetic structure with RAPD markers. Mol Ecol 3:91-99

Maguire TL, Peakall R, Saenger P (2002) Comparative analysis of genetic diversity in the mangrove species Avicennia marina (Forsk.) Vierh. (Avicenniaceae) detected by AFLPs and SSRs. Theor Appl Genet 104:388-398. doi:10.1007/s001220100724

Manly BFJ (1997) Randomization, bootstrap and Monte Carlo methods in biology. Chapman \& Hall, London

Mantel N (1967) The detection of disease clustering and a generalized regression approach. Can Res 27:209-220

Meffe GK, Carroll CR (1997) Principles of conservation biology. Sinauer, MA

Mello CMC (2001) Conservação de sementes de orquídeas do Cerrado. Acta Bot Bras 15:287. doi:10.1590/S0102-33062001000200020 
Menezes LC (2002) Cattleya labiata autumnalis. Edições IBAMA, Brasília

Michalakis Y, Excoffier L (1996) A generic estimation of population subdivision using distances between alleles with special reference for microsatellite loci. Genetics 142:1061-1064

Muñoz M, Warner J, Albertazzi FJ (2010) Genetic diversity analysis of the endangered slipper orchid Phragmipedium longifolium in Costa Rica. Plant Syst Evol 290:217-223. doi:10.1007/s00606010-0362-6

Myers N, Mittermeier RA, Mittermeier CG, da Fonseca GAB, Kent J (2000) Biodiversity hotspots for conservation priorities. Nature 403:853-858

Niknejad A, Kadir MA, Kadzimin SB, Abdullah NAP, Sorkheh K (2009) Molecular characterization and phylogenetic relationships among and within species of Phalaenopsis (Epidendroideae: Orchidacheae) base on RAPD analysis. Afr J Biotechnol 8:5225-5240

Nybom H, Bartish IV (2000) Effects of life history traits and sampling strategies on genetic diversity estimates obtained with RAPD markers in plants. Perspect Plant Ecol Evol Systemat 3:93-114. doi:10.1078/1433-8319-00006

Oliveira LO, Venturini BA, Rossi AAB, Hastenreiter SS (2010) Clonal diversity and conservation genetics of the medicinal plant Carapichea ipecacuanha (Rubiaceae). Genet Mol Biol 33:8693. doi:10.1590/S1415-47572009005000096

Pabst GFJ, Dungs F (1975) Orchidaceae brasiliensis I. Brücke-Verlag, Hildesheim

Parab GV, Krishnan S (2008) Assessment of genetic variation among populations of Rhynchostylis retusa, an epiphytic orchid from Goa, India using ISSR and RAPD markers. Indian J Biotechnol 7:313-319

Pereira L, Kasuya MCM, Rollemberg CL, Chaer GM (2005) Isolamento e identificação de fungos micorrízicos rizoctonióides associados a três espécies de orquídeas epífitas neotropicais no Brasil. R Bras de Ciên do Solo 29:191-197. doi:10.1590/S010006832005000200004

Pridgeon AM (1992) The illustrated encyclopaedia of orchids. Timber, Portland

Pritchard JK, Stephens M, Donnelly P (2000) Inference of population structure using multilocus genotype data. Genetics 155:945-959

Qamaruz-Zaman F, Fay MF, Parker JS, Chase MW (1998) Molecular techniques employed in the assessment of genetic diversity: a review focusing on orchid conservation. Lindleyana 13:259-283

Ramos JR, Telles MP, Diniz-Filho JA, Soares TN, Melo DB, Oliveira G (2008) Optimizing reproducibility evaluation for random amplified polymorphic DNA markers. Genet Mol Res 7:13841391. doi:10.4238/vol7-4gmr520

Rodrigues JF (2010) Delimitação de species e diversidade genética no complexo Cattleya coccinea Lindl. e C. mantiqueirae (Fowlie)
Van Den Berg (Orchidaceae) baseada em marcadores moleculares ISSR. Dissertation, Universidade de São Paulo

Santos ARF, Ramos-Cabrer AM, Diaz-Hernandez M, Pereira-Lorenzo S (2011) Genetic variability and diversification process in local pear cultivars from northwestern Spain using microsatellites. Tree Gen and Genome. doi:10.1007/s11295-011-0393-3

Selkoe KA, Toonen RJ (2006) Microsatellites for ecologists: a practical guide to using and evaluating microsatellite markers. Ecol Let 9:615-629

Shaw RK, Acharya LK, Mukherjee AK (2009) Assessment of genetic diversity in a highly valuable medicinal plant Catharanthus roseus using molecular markers. Crop Breed Appl Biotech 9:52-59

Silva AVC, Santos ARF, Lédo AS, Feitosa RB, Almeida CS (2012) Moringa genetic diversity from germplasm bank using RAPD markers. Trop Subtrop Agroec 15:31-39

Smith JL, Hunter KL, Hunter RB (2002) Genetic variation in the terrestrial orchid Tipularia discolor. Sena 1:17-26. doi:10.1656/ 1528-7092(2002)001[0017:GVITTO]2.0.CO;2

Soul'e M (1986) Conservation biology, the science of scarcity and diversity. Sinauer, MA

Sun M, Wong KC (2001) Genetic structure of three orchid species with contrasting breeding systems using RAPD and allozyme markers. Am J Bot 88:2180-2188

Sundberg MI, Slaughter DM, Crupper SS (2002) Application of randomly amplified polymorphic DNA (RAPD) fingerprinting to detect genetic variation in Sericea Lespedeza (Lespedeza cuneata). Trans Kansas Acad Sci 105:91-95. doi:10.1660/00228443(2002)105[0091:AORAPD]2.0.CO;2

Swarts ND, Sinclair EA, Krauss SL, Dixon KW (2009) Genetic diversity in fragmented populations of the critically endangered spider orchid Caladenia huegelii: implications for conservation. Conservat Genet 10:199-208. doi:10.1007/s10592-008-9651-9

Trapnell WD, Hamrick JL, Nason JD (2004) Three-dimensional finescale genetic structure of the neotropical epiphytic orchid, Laelia rubescens. Mol Ecol 13:1111-1118

Wallace LE (2003) Molecular evidence for allopolyploid speciation and recurrent origins in Platanthera huronensis (Orchidaceae). Int J Plant Sci 164:907-916. doi:10.1086/378658

Wang RL, Stec A, Hey J, Likens L, Doebley J (1999) The limits of selection during maize domestication. Nature 398:236-239

Wang HZ, Wu ZX, Lu JJ, Shi NN, Zhao Y, Zhang ZT, Liu JJ (2009) Molecular diversity and relationships among Cymbidium goeringii cultivars base on inter-simple sequence repeat (ISSR) markers. Genetica 136:391-399. doi:10.1007/s10709-008-9340-0

Yanaka YF, Dall'Agnol M, Schifino-Wittmann MT, Barreto Dias PM, Gomes KE (2005) Variabilidadegenética em populações naturais de Bromus auleticus Trin. ex Nees (Poaceae) com base em isoenzimas e marcadores RAPD. Rev Bras Zootec 34:1897-1904 